\title{
Correlation of Serum Vitamin-D Level with Coronary Angiographic Severity In Patients with Acute Coronary Syndrome
}

\author{
KAMRUZZAMAN SIDDIKI ${ }^{1}$, MD. HARISUL HOQUE ${ }^{1}$, MD. MUKHLESUR RAHMAN ${ }^{1}$, \\ MD. FAKHRUL ISLAM KHALED ${ }^{1}$, FYSAL FARUQ ${ }^{1}$, MD. MASHIULALAM ${ }^{2}$, MD.AHSANUL KABIR ${ }^{3}$, \\ SAYED NAZMUL ISLAM ${ }^{4}$, MD. AZHARUL ISLAM ${ }^{1}$, S.M. MUSTAFA ZAMAN ${ }^{1}$
}

${ }^{1}$ Department of Cardiology, University Cardiac Centre, Bangabandhu Sheikh Mujib Medical University (BSMMU), Shahbagh, Dhaka, ${ }^{2}$ Department of Cardiology, Jahurul Islam Medical College, Bajitpur, Kishorgonj, ${ }^{3}$ Department of Pharmacology, Satkhira MewdicaLCollege, Satkhira, ${ }^{4}$ Banaripara Upazila Health Complex, Barishal.

Address of Correspondence: Dr. Kamruzzaman Siddiki, Phase-B, Resident, Department of Cardiology, University Cardiac Centre (UCC), Bangabandhu Sheikh Mujib Medical University (BSMMU), Shahbagh, Dhaka. E-mail :siddiki88@gmail.com

\begin{abstract}
:
Background: Acute Coronary Syndrome includes to a group of conditions compatible with acute myocardial ischemia and/or infarction that are usually due to an abrupt reduction in coronary blood flow. In the last decade vitamin-D deficiency as a predisposing factor for coronary artery disease is in growing interest. Prospective studies give conflicting results regarding correlation of serum vitamin D level with coronary angiographic severity in patients with acute coronary syndrome.
\end{abstract}

Objective: To study the correlation between serum vitamin-D level with coronary angiographic severity in patients with acute coronary syndrome.

Methodology: This cross sectional observational study was done between November 2018 and October 2019. Total 71 patients with diagnosis of first incident of acute coronary syndrome in department of cardiology, BSMMU who were underwent coronary angiogram included in this study considering the inclusion and exclusion criteria. Vitamin D was measured by chemiluminescent immunoassay after collection of venous blood at Department of Biochemistry, BSMMU. Angiographic severity was assessed by using Gensini score. Statistical analyses were carried out by using the Statistical Package for Social Sciences version 23.0 for Windows (SPSS Inc., Chicago, Illinois, USA).

Results: The mean age was found $55.9 \pm 10.7$ years with a range from 36 to 82 years. Majority (83.1\%) patients were male. The male-female ratio was 4.9:1. Thirty (42.3\%) of the patients had STEMI, 28(39.4\%) had NSTEMI and 13(18.3\%) had unstable angina. Negative correlation $(r=-0.479 ; p=0.001)$ was found between serum vitamin D level and Gensini score in patients with acute coronary syndrome.

Conclusion: In this study found that serum vitamin-D level is inversely correlated with angiographic severity in patients with acute coronary syndrome.

Key words: Acute Coronary Syndrome, Gensini score, serum vitamin-D.

University Heart Journal 2021; 17(2): 103-107

Introduction:

Cardiovascular diseases account for more than 17 million deaths globally each year. It contributes $30 \%$ of all deaths, $80 \%$ of those occur in low-income and middle-income countries. This figure is to grow to 23.6 million by the year 2030. Coronary artery disease alone caused 7 million deaths worldwide in 2010. It is an increase of $35 \%$ since $1990 .{ }^{1}$

Acute coronary syndrome (ACS), defined as the of STsegment elevation myocardial infarction (STEMI), non-
ST-segment elevation myocardial infarction (NSTEMI), and unstable angina, is a severe presentation of cardiovascular diseases. Acute coronary syndrome (ACS) is the important cause of mortality and morbidity. It is usually caused acute change in atherosclerotic plaque. During the past 2 decades, extensive research has established that atherosclerosis is an inflammatory disease. All ACS events result from coronary atherosclerosis, generally with superimposed coronary thrombosis caused by rupture or erosion of an atherosclerotic lesion. ${ }^{2}$ 
Several studies have found that systemic inflammation in ACS as assessed by the biomarker CRP. ${ }^{3}$ Laboratory studies and observations on human plaques point to inflammatory mechanisms as key regulators of the fragility of the fibrous cap and of the thrombogenic potential of the lipid core.

Vitamin D is a fat-soluble vitamin. It exists in many forms but two forms are very important: 25-hydroxycholecalciferol and 1, 25 dihydroxycholecalciferol. ${ }^{4}$ In the skin provitamin D is photo-isomerized to vitamin D3. Calcitriol mediates its biological effects by binding to the vitamin D receptor (VDR), located in the nuclei of target cells in most organs. The binding of calcitriol to the VDR allows the VDR to act as a transcription factor that modulates the gene expression of transport proteins involved in a multitude of different tasks. ${ }^{5}$

Vitamin D suppresses inflammation via several pathways, such as inhibition of prostaglandin and cyclooxygenase pathways, upregulation of anti-inflammatory cytokines, decrease of cytokine induced expression of adhesion molecules, reduction of matrix metalloproteinase ${ }^{9}$ and down regulation of the RAAS., ${ }^{6,7}$ Vitamin D deficiency stimulates systemic and vascular inflammation, enabling atherogenesis. $^{8}$

The Gensini score was developed by Gensini and takes into consideration the geometrical severity of lesions by angiography, the cumulative effects of multiple obstructions and the significance of jeopardized myocardium. ${ }^{9}$

Recent studies provide conflicting results regarding correlation of serum vitamin-D level with angiographic severity in patient with acute coronary syndrome. The aim of this study was to correlate serum vitamin-D level with angiographic severity by Gensini score in patient with acute coronary syndrome.

\section{Materials \& Methods:}

This was cross sectional observational study done between November 2018 and October 2019. Total 75 patients with diagnosis of first incident of acute coronary syndrome in department of cardiology, BSMMU who were underwent coronary angiogram included in this study.Patients with (history of recent vitamin D supplement, receiving any medications that may alter Vitamin-D level, history of any malignancies, endocrine disorders like Hyperthyroidism, Hyperparathyroidism, chronic liver disease, chronic kidney disease, heart failure, connective tissue diseases like gout, malabsorption syndrome, pregnancy and lactation were exclusion criteria.

The purpose and procedure of the study was discussed with the patient and informed written consent was taken. After getting consent, meticulous history including demographic data, risk factors profile was taken and relevant clinical examination was performed and recorded in predesigned structured data sheet. Standard 12 lead ECG was recorded at a $25 \mathrm{~mm} / \mathrm{s}$ paper speed and a gain of $10 \mathrm{~mm} / \mathrm{mV}$ with the patient fully relaxed in the supine position. Serum Troponin-I concentration was done. Transthoracic echocardiography was done to assess the RWMA, LV dysfunction, LVEF \& Mechanical complication with standard echocardiographic measurements was done before coronary angiogram. Vitamin- D level was measured by chemiluminescent immunoassay after collection of 02 $\mathrm{ml}$ of venous blood in department of biochemistry, BSMMU. The ARCHITECT 25(OH) vitamin- D assay is a chemiluminescent microparticle immunoassay for the quantitative determination of $25(\mathrm{OH})$ vitamin $\mathrm{D}$ in human serum and plasma. Serum vitamin D levels were categorized according to Institute of Medicine Report and Society of Endocrine Guideline 2011. All the enrolled patients were undergone invasive evaluation by coronary angiography during index hospitalization. Diagnostic coronary angiography was performed via either the trans-femoral or trans-radial approach by expert interventional cardiologist using standard techniques. Then angiographic severity was assessed by using Gensini score. Finally 71 data were analyzed and 04 data were discarded due to in complete information.

Statistical analysis: were carried out by using the Statistical Package for Social Sciences (SPSS) version 23.0 for Windows Software. Continuous data were expressed as mean \pm standard deviation (SD) and categorical data were expressed as frequency and percentages. Mean and standard deviation were computed for quantitative variables and was analyzed by unpaired t-test. The correlation of vitamin D level with the Gensini score was done by Pearson's correlation coefficient test. P values $<0.05$ was considered as statistically significant.

\section{Results:}

The mean age was found $55.9 \pm 10.7$ years with a range from 36 to 82 years. Majority (83.1\%) patients were male. The male-female ratio was $4.9: 1$. Thirty $(42.3 \%)$ of the patients had STEMI, 28(39.4\%) had NSTEMI and $13(18.3 \%)$ had unstable angina. Negative correlation $(\mathrm{r}=-0.479 ; \mathrm{p}=0.001)$ was found between serum vitamin $\mathrm{D}$ level and Gensini score in patients with acute coronary syndrome. 
Table-I

Baseline characteristics of study population $(n=71)$

\begin{tabular}{|c|c|c|}
\hline Parameters & er of patients & Percentage \\
\hline Mean age (years) & $5.9 \pm 10.7$ & \\
\hline \multicolumn{3}{|l|}{ Sex } \\
\hline Male & 59 & 83.1 \\
\hline Female & 12 & 16.8 \\
\hline \multicolumn{3}{|l|}{ Occupation } \\
\hline Businessman & 28 & 39.4 \\
\hline Service holder & 20 & 28.2 \\
\hline Housewife & 12 & 16.9 \\
\hline Retried & 10 & 14.1 \\
\hline Farmer & 1 & 1.4 \\
\hline \multicolumn{3}{|l|}{ Residence } \\
\hline Urban & 47 & 66.2 \\
\hline Rural & 24 & 33.8 \\
\hline \multicolumn{3}{|l|}{$\operatorname{BMI}\left(\mathrm{kg} / \mathrm{m}^{2}\right)$} \\
\hline Normal $\left(18.5-22.9 \mathrm{~kg} / \mathrm{m}^{2}\right)$ & 45 & 63.38 \\
\hline Overweight $\left(23.0-24.9 \mathrm{~kg} / \mathrm{m}^{2}\right)$ & 21 & 29.58 \\
\hline Obese $\left(\geq 25.0 \mathrm{~kg} / \mathrm{m}^{2}\right)$ & 5 & 7.04 \\
\hline \multicolumn{3}{|l|}{ Risk factors } \\
\hline Smoking & 47 & 66.2 \\
\hline Dyslipidemia & 38 & 53.5 \\
\hline Hypertension & 38 & 53.5 \\
\hline Diabetes mellitus & 35 & 49.3 \\
\hline Family history of IHD & 30 & 42.3 \\
\hline \multicolumn{3}{|l|}{ Mode of presentation } \\
\hline STEMI & 30 & 42.3 \\
\hline NSTEMI & 28 & 39.4 \\
\hline Unstable angina & 13 & 18.3 \\
\hline
\end{tabular}

Table-II

Distribution of the study population according to serum vitamin D 25-hydroxyvitamin $(n=71)$

\begin{tabular}{lcc}
\hline $\begin{array}{l}\text { Serum vitamin D 25- } \\
\text { hydroxyvitamin (ng/ml) }\end{array}$ & $\begin{array}{c}\text { Number of } \\
\text { patients }\end{array}$ & Percentage \\
\hline 10-19.9 (Mild- moderate deficiency) & 38 & 53.5 \\
20-29.9 (Insufficiency) & 25 & 35.2 \\
e"30 (Sufficiency) & 8 & 11.3 \\
Mean \pm SD & 20.8 & \pm 7.0 \\
Range (min-max) & 10.1 & -40.0 \\
\hline $\mathrm{n}=$ Number of study population & \\
$\mathrm{SD}=$ Standard deviation & \\
More than half 38(53.5\%) of the patients were found serum \\
vitamin D 25-hydroxyvitamin level 10-19.9 ng/ml,25(35.2\%) \\
were found 20-29.9 ng/ml (Insufficiency) and 08(11.3\%) \\
were found $\geq 30$ (Sufficiency). Mean serum vitamin D 25- \\
hydroxyvitamin level was found 20.8 \pm 7.0 $\mathrm{ng} / \mathrm{ml}$ with a range \\
from 10.1 to $40.0 \mathrm{ng} / \mathrm{ml}$.
\end{tabular}

\section{Table III}

Distribution of the study population according to Gensini score $(n=71)$

\begin{tabular}{lcc}
\hline Gensini score & Frequency & Percentage \\
\hline$<36$ (absent or mild coronary & 20 & 28.2 \\
atherosclerosis) & & \\
$\geq 36$ (moderate to severe coronary & 51 & 71.8 \\
atherosclerosis) & & \\
Mean \pm SD & 49.7 & \pm 26.2 \\
Range & 8.0 & -112.0 \\
\hline
\end{tabular}

$\mathrm{n}=$ Number of study population

$\mathrm{SD}=$ Standard deviation

Almost three fourth 51(71.8\%) patients had Gensini score $\geq 36$ (moderate to severe coronary atherosclerosis). Mean Gensini score was found to have $49.7 \pm 26.2$ with a range from 8.0 to 112.0 .

Table-IV

Association between serum vitamin D level with Gensini score $(n=71)$

\begin{tabular}{|c|c|c|c|c|c|}
\hline \multirow[t]{3}{*}{ Serum vitamin $\mathrm{D}(\mathrm{ng} / \mathrm{ml})$} & \multicolumn{4}{|c|}{ Gensini score } & \multirow[t]{3}{*}{$\mathrm{P}$ value } \\
\hline & \multicolumn{2}{|c|}{$\geq 36(\mathrm{n}=51)$} & \multicolumn{2}{|c|}{$<36(\mathrm{n}=20)$} & \\
\hline & $\mathrm{n}$ & $\%$ & $\mathrm{n}$ & $\%$ & \\
\hline 10-19.9 (Mild- moderate deficiency) & 33 & 64.7 & 5 & 25.0 & \\
\hline 20-29.9(Insufficiency) & 17 & 33.3 & 8 & 40.0 & \\
\hline$\geq 30$ (Sufficiency) & 1 & 2.0 & 7 & 35.0 & \\
\hline Mean \pm SD & 18.6 & \pm 5.3 & 26.3 & \pm 8.0 & $0.001^{\mathrm{s}}$ \\
\hline Range & 10.1 & -31.3 & 11.8 & -40.0 & \\
\hline
\end{tabular}

$\mathrm{n}=$ Number of study population

$\mathrm{SD}=$ Standard deviation

$\mathrm{s}=$ significant

$P$ value reached from unpaired t-test 
Majority 33(64.7\%) of the patients were found serum vitamin D level 10-19.9 ng/ml in Gensini score $\geq 36$ and $5(25.0 \%)$ in Gensini score $<36$. Mean serum vitamin $\mathrm{D}$ was $18.6 \pm 5.3 \mathrm{ng} / \mathrm{ml}$ in Gensini score $\geq 36$ and $26.3 \pm 8.0 \mathrm{ng} / \mathrm{ml}$ in Gensini score $<36$. The difference was statistically significant $(\mathrm{p}<0.05)$ between two groups.

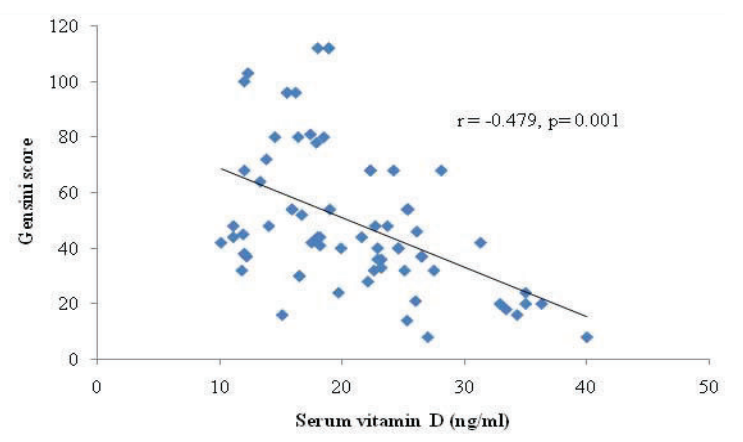

Fig.-1: Scatter diagram showing negative correlation $(r=-0.479 ; p=0.001)$ between serum vitamin $D$ level and Gensini score in patients with acute coronary syndrome.

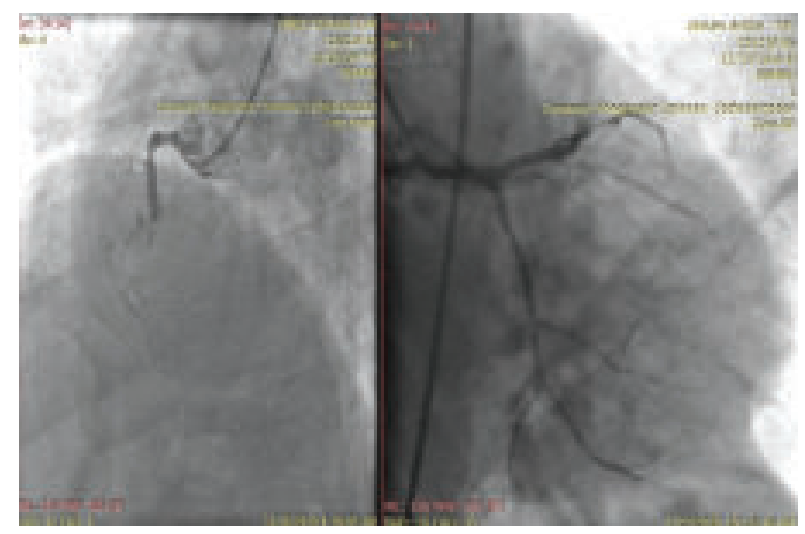

Fig.-2: (a) shows total occlusion of RCA and FigureII(b) shows significant stenosis in LAD and LCX of a study population.

\section{Discussion:}

This study observed that the mean age was found $55.9 \pm 10.7$ years with a range from 36 to 82 years and the majority $27(38.0 \%)$ of the patients belonged to age 51-60 years. ${ }^{10}$ study showed that age of the patients with documented coronary artery disease ranged between $29-70$ years with a mean of $51.6 \pm 10.3$ years. Out of 102,77 (75.5\%) patients' age was 45 years or more. ${ }^{11}$ Also found mean age was $63.3 \pm 18.5$ years These study results were similar with our findings.

This study found that the majority $59(83.1 \%)$ patients were male and $12(16.9 \%)$ were female. The male-female ratio was 4.9:1. ${ }^{10}$ reported similar observation they showed 80 (78.4\%) were males and $22(21.6 \%)$ were females.

This study showed that $30(42.3 \%)$ of the patients had STEMI, 28(39.4\%) had NSTEMI and 13(18.3\%) had unstable ngina. In study of ${ }^{10}$ reported that patients admitted with acute coronary syndrome, $44.2 \%$ of were with non-ST-segment elevation ACS and the remaining with STEMI.

This little difference between our study and previous study may due to most of the patients in BSMMU, UCC admitted from referral hospital with STEMI for PCI.

This study observed that more than half $38(53.5 \%)$ patients were found serum vitamin D 25-hydroxyvitamin level 10$19.9 \mathrm{ng} / \mathrm{ml}, 25(35.2 \%)$ were found $20-29.9 \mathrm{ng} / \mathrm{ml}$ (Insufficiency) and 08(11.3\%) were found $\geq 30$ (Sufficiency). Mean serum vitamin D 25-hydroxyvitamin was found $20.8 \pm 7.0 \mathrm{ng} / \mathrm{ml}$ with a range from 10.1 to 40.0 $\mathrm{ng} / \mathrm{ml}$. Approximately similar observation was found ${ }^{9}$ they reported out of 102 patients, with documented coronary artery disease $75(73.5 \%)$ patients had Vitamin D level $<30$ $\mathrm{ng} / \mathrm{ml}$, while 27 (26.5\%) patients had normal level ( $\geq 30 \mathrm{ng} / \mathrm{ml})$.

This study found that majority of the $46(64.7 \%)$ patients were found serum vitamin D level 10-19.9 ng/ml in Gensini score $\geq 36$ and $5(25.0 \%)$ in Gensini score $<36$. Mean serum vitamin D was $18.6 \pm 5.3 \mathrm{ng} / \mathrm{ml}$ in Gensini score $\geq 36$ and $26.3 \pm 8.0 \mathrm{ng} / \mathrm{ml}$ in Gensini score $<36$. The difference was statistically significant $(\mathrm{p}<0.05)$ between two groups. ${ }^{10}$ also revealed that major proportion $(75 \%)$ of patients with vitamin D deficiency and $64.1 \%$ with vitamin D insufficiency had Gensini score $\geq 36$. All the patients with normal vitamin D level ( $\geq 30 \mathrm{ng} / \mathrm{mL})$ had Gensini score $<36$. The difference was statistically highly significant between the two groups $(p=0.001)$ and was comparable with our findings.

In this study negative correlation $(\mathrm{r}=-0.479 ; \mathrm{p}=0.001)$ was found between serum vitamin D level and Gensini score in patients with acute coronary syndrome ${ }^{12}$ studied the correlation between serum vitamin D level with coronary angiographic severity with 239 patients who underwent coronary angiogram, They observed significant inverse correlation between serum $25(\mathrm{OH})$ D levels and the severity of coronary artery disease assessed by Gensini score $(\mathrm{r}=-0.416, \mathrm{P}<0.001)$, which is comparable to this study result. ${ }^{10}$ studied the correlation between serum vitamin $\mathrm{D}$ level with angiographic severity in 102 patients with documented coronary artery disease by Gensini score. Where they found serum vitamin D level is inversely 
cor-related with Gensiniscore ( $\mathrm{r}=-0.667, \mathrm{p}=0.001)$, which have similarity to this study result. ${ }^{13}$ studied the relationship between combination of serum vit $-\mathrm{D}$ deficiency and hyperuricemia and severity of coronary artery disease in 502 myocardial infraction patients. From sub group analysis they found that low serum vitamin-D level had higher gensini score than control group $(\mathrm{p}=0.019)$, which also support this study result.

\section{Conclusion:}

This study found that serum vitamin-D level is inversely correlated with angiographic severity in patients with acute coronary syndrome. A high prevalence of hypovitaminosis was observed in the study population.

\section{Limitations}

Sample was taken from a single centre, so result may not represent the whole country. Observational nature of the study and there was lack of randomization, so causality cannot be assessed. Vitamin-D levels can also change depending on seasons which were not evaluated in this study.

\section{Conflict of interest}

The authors declare that there is no conflict of interest.

\section{References:}

1. Wong CK, Freedman SB, Bautovich G, Bailey BP, Bernstein L, Kelly DT. and significance of precordial ST-segment depression during inferior wall acute myocardial infarction associated with severe narrowing of the dominant right coronary artery. The American journal of cardiology. 1993 May 1;71(12):1025-30.

2. Falk E, Nakano M, Bentzon JF, Finn AV, Virmani R. Update on acute coronary syndromes: the pathologists' view. European heart journal. 2013 Mar 7;34(10):719-28.

3. Liuzzo, G., Biasucci, L.M., Gallimore, J.R., Grillo, R.L., Rebuzzi, A.G., Pepys, M.B. and Maseri, A. The prognostic value of Creactive protein and serum amyloid a protein in severe unstable angina. New England journal of medicine, 1994;331(7): 417-24.
4. Brandi ML. Indications on the use of vitamin D and vitamin D metabolites in clinical phenotypes. Clinical Cases in Mineral and Bone Metabolism. 2010 Sep;7(3):243.

5. Ab Hameed Raina MS, Shah ZA, Changal KH, Raina MA, Bhat FA. Association of low levels of vitamin D with chronic stable angina: A prospective case-control study. North American journal of medical sciences. 2016 Mar;8(3):143.

6. Kunadian V, Ford GA, Bawamia B, Qiu W, Manson JE. Vitamin D deficiency and coronary artery disease: a review of the evidence. American Heart Journal. 2014 Mar 1;167(3):283-91.

7. Ferder M, Inserra F, Manucha W, Ferder L. The world pandemic of vitamin D deficiency could possibly be explained by cellular inflammatory response activity induced by the reninangiotensin system. American Journal of Physiology-Cell Physiology. 2013 Jun 1;304(11):C1027-39.

8. Lee JH, O'Keefe JH, Bell D, Hensrud DD, Holick MF. Vitamin D deficiency: an important, common, and easily treatable cardiovascular risk factor?. Journal of the American College of Cardiology. 2008 Dec 9;52(24):1949-56.

9. Gensini GG. A more meaningful scoring system for determining the severity of coronary heart disease. Am J cardiol. 1983;51:606.

10. Rahman AU, Karmakar PK, Jabeen S, Nabi S, Khan AM, Shahriar S, Alam I, Chakraborty S, Matin MA, Azam SA. Association of Vitamin D Level with Severity of Angiographically Documented Coronary Artery Disease: Observations from Bangladeshi Patients. Journal of Cardiovascular Disease Research. 2019;10(2).

11. Bakt1r AO, Doan Y, ^arl1 B, ^ahin Ö, Demirci E, Akpek M, Özkan E, Ar1nç H, Salam H. Relationship between serum 25hydroxyvitamin D levels and the SYNTAX score in patients with acute coronary syndrome. Anatolian journal of cardiology. 2017 Apr;17(4):293.

12. Akin F, Ayça B, Köse N, Duran M, Sar1 M, Uysal OK, Karakukcu C, Arinc H, Covic A, Goldsmith D, Okçün B. Serum vitamin D levels are independently associated with severity of coronary artery disease. Journal of Investigative Medicine. 2012 Aug 1;60(6):869-73.

13. Somuncu, M.U., Serbest, N.G., Akgül, F., Çak1r, M.O., Akgün, T., Tatar, F.P. et al. The relationship between a combination of vitamin D deficiency and hyperuricemia and the severity of coronary artery disease in myocardial infarction patients. Archives of the Turkish Society of Cardiology, 2020;48(1):10-19. 